\title{
EFFECT OF CUSTOMER SERVICE ON CORPORATE COMPETITIVE ADVANTAGE IN THE NIGERIAN TELECOMS SERVICE INDUSTRY
}

\author{
Patrick Kunle Adeosun LADIPO \\ University of Lagos Nigeria \\ Email: pkaladipo@gmail.com \\ Ismail Tubosun AREBI* \\ University of Lagos, Nigeria \\ Email: arebi.ismail@gmail.com \\ Olushola Solomon AKEKE \\ University of Lagos, Nigeria \\ Email: solomonyz4real@yahoo.com \\ Babatunde BISIRIYU \\ University of Lagos, Nigeria \\ Email: gbekebisiriyu@gmail.com
}

DOI: 10.52846/MNMK.19.2.05

\begin{abstract}
:
This study is carried out to examine the effect of customer service on the corporate competitive advantage from the perspective of selected firms in the Nigerian telecom service industry. It was a quantitative study under which suitable research methods were utilized. A sample of 420 was drawn from the 22.6 million population of telecom service subscribers in Lagos state, Nigeria. A Cronbach Alpha statistical coefficient was used to ensure the consistency and accuracy of the questionnaire instrument. The finding reveals that customer service components such as quality call network, fast data connection, customer correspondence, customer support and warranty are significantly related to achieving a competitive advantage in the Nigerian Telecom service industry. However, the fast data connection is identified as customers' reasons for choosing one telecom service provider over another. Therefore, the study recommends that customer service should be improved upon for the firms in this industry to achieve significant growth and sustainability.
\end{abstract}

Keywords: Customer service, quality call network, fast data connection, customer correspondence, customer support, warranty, corporate competitive advantage

\section{Introduction}

The telecoms industry all around the world has over the years grown and experienced several dynamic changes, as result in globalization, liberalization and deregulation which has increased the number of players and hence intensified the

\footnotetext{
* Corresponding author
} 
level of competition (Oghojafor, Ladipo et al, 2014; Akingbade, 2021). Also in Nigeria, the telecom service industry is known to be a major contributor to the economy (Matthew, Kazaure et al, 2021). For instance, the industry contributed N1.58 billion to the Gross Domestic Product (henceforth, GDP) in 2016 and a $12.45 \%$ increment in the year 2020 (Ishola and Olusoji, 2020). This contribution has thus increased over time as the industry shows a positive trend in growth as the largest contributor to GDP when compared to other sectors and industries in Nigeria (Adeleke, 2020). This industry impact on the economy can nowhere be achieved without the telecom service subscribers which has tremendously increased since its introduction to the country in the year 2001. According to the National Bureau of Statistics (2016) there exist four major players in the Nigerian telecoms industry with a top share of subscribers such as MTN $39 \%$, Globacom $24 \%$ Airtel $21 \%$, and 9 mobile $15 \%$. As of 2005 , the total number of subscribers was $19,519,154$, a decade later the figure increased to 151,017,244 (Oyedijo, 2012; National Bureau of statistics, 2016). The level of activities in the telecoms industry has increased significantly making competition increased too, while companies are finding various ways to stay ahead of this competition. This is done by using various marketing strategies to attract, maintain and retain subscribers (Oyedijo, 2012; Lim, Yeo et al, 2018).

Generally speaking, the services rendered by telecom provider is similar in nature such as network calls, short messaging services and data/internet services, while the pricing and charges for the services among key players in the industry are somewhat homogenous in nature. In essence, customer service in the telecom service industry is a critical aspect of the marketing concept which postulates that the customer is at the centre of all marketing activities thus there is a need to create tactics to improve the way services are rendered to customers. And based on the increasingly intense competition in the business world today, many companies are lead to finding diverse ways of overcoming their competitors. This is where the concept of competitive advantage is introduced in this research study. According to Wheelen and Hunger (2012), competitive advantage is the ability of an organization to deliver superior products, services and experiences to the customer at a lower price than that of competitors. A competitive advantage is an advantage over competitors gained by offering consumers greater value, either through lower prices or by providing greater benefits and service that justifies higher prices (Kazmi, 2008; Wheelen and Hunger, 2012). Therefore, the purpose of this study is to examine the effect of customer service on corporate competitive advantage in the Nigerian telecoms service industry. The perspective of some selected telecom customers in the Lagos State area of Nigeria is taken for providing systematic answers to the research questions.

\section{Theoretical Framework}

\subsection{Resource Advantage Theory}

This theory was established by Hodgson (1993) taxonomy, from the resourcebased model of Barney (1991). It is an evolutionary disequilibrium provoking process theory of competition in which factors of innovation and organizational learning are critical. This model recognizes the importance of a firm's internal organizational resources as determinants of the organizational marketing strategy and performance (Hunt and Arnett, 2004). It is a managerial framework used to determine the strategic 
resources a firm can exploit to achieve sustainable competitive advantage (Wheelen and Hunger, 2012). The theory proposes that firms are heterogeneous. They possess heterogeneous resources, meaning firms can have different strategies because they have different resource mixes. The resources advantage theory emphasised that managerial attention is required on the firm's internal resources to identify assets, capabilities and competencies with the potential to deliver superior competitive advantage. This theory is relevant in this research as it focuses on how organizational resources can be used to drive customer service towards achieving a competitive advantage in the telecom service industry.

\subsection{Porter Theory of Competitive Advantage}

The theory of competitive advantage by Micheal E. Porter originates from his works of 1980-1985 explaining that competition determines the appropriateness of a firm's activities that can contribute to its performance, such as innovations, a cohesive culture, or good implementation. According to Kazmi (2011), the utilization of technology in organizational strategy creates scope for resources and capabilities to be innovate maximized in terms of competition. Porter's theory of 1985 explains the competitive advantage of an organization, it's the unique ability of an organization to fight competition and establish its market share. Hence Porter's theoretical framework emphasizes two major Generic competitive advantage strategies; Cost strategy and differentiation strategy. The alternative banking channels is based on this theory of competitive advantage viewed from the fact that it can link cost and differentiation based on organizational ability to capture the market via online strategies in reaching the customer. In essence, the competitive advantage theory bases the need for organizations to focus business operations and processes on where they can deliver superior value.

\section{Problem Statement and Research Questions}

The telecoms service providers in Nigeria have been overwhelmed over the years with complaints of ineffective customer service in terms of inadequate handling of customer issues, unsolicited promotion, slow response time, lack of communication and feedback when utilizing products and services (Akingbade, 2021). There seems to have caused customers to switch from one telecoms provider to the other which in turn negatively impacts sales, patronage and profitability. Based on the persistence of these problems there is a need to investigate the significant effect of customer service towards improving competitive advantage among companies operating in the industry. In addition, scholars (see, David Mc, 2013; Steven, Yazdi et al, 2016; Hallencreutz and Parmler, 2019; Xiao and Kumar, 2021) argued that the quality and level of customer service has decreased in recent years, which is attributed to a lack of support or understanding at the executive and middle management levels of a corporation and/or a customer service policy. On this view, many organizations have to implement a variety of methods to improve their customer satisfaction levels, and other key performance indicators to achieve competitive advantage. However, the understanding of customers' needs is very crucial to the companies operating in the Nigerian telecoms service industry. Also, organisations in this industry need a shift from product/service focus to customer's needs and want towards achieving a sustainable competitive edge in the market. Also, the outcome of this study is important for the policymakers and regulating bodies in the telecom service industry to improve their assessment of both the 
organisations and their customers concerning the impact of customer service on the growth of the economy at large. Therefore, this study seeks to bridge the gap in literature and business knowledge by investigating the effect of customer service on corporate competitive advantage based on the perspective of selected firms in the telecom service industry in Nigeria. The following research questions are coined as the basis and relevant variables for addressing the research problems.

i. What is the relationship between quality call network and competitive advantage?

ii. What is the relationship between fast data connection and competitive advantage?

iii. What is the relationship between customer correspondence and competitive advantage?

iv. What is the relationship between customer support and competitive advantage?

v. What is the relationship between warranty and competitive advantage?

\section{Conceptual Model and Hypothesis Development}

The study model is depicted to show the effect of customer service on corporate competitive advantage. The independent variable is customer service while the dependent variable is a competitive advantage. The model was adopted from the previous related empirical studies such as Kursunluoglu (2011), Minh and Huu, (2016), Lewis and Mitchell (2018), and Desfitrina, Zulfadhli et al (2019) based on their previous investigations on customer service. The study model is diagrammatically depicted below:

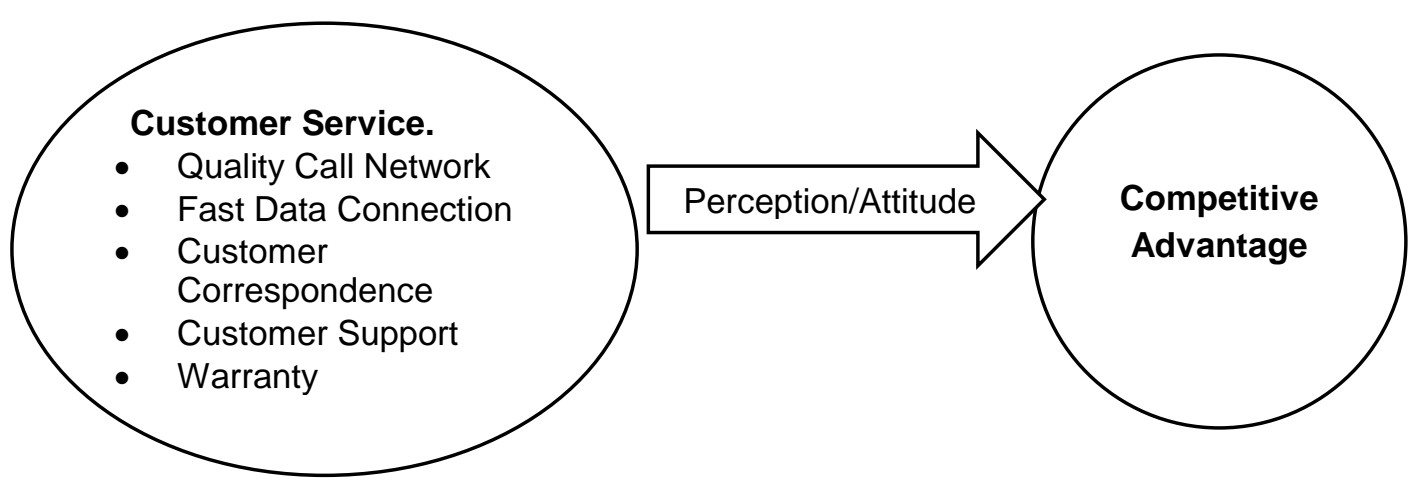

Figure 1. Conceptual Model of the Study

Source: Developed by the authors

Based on this model, below are the highlighted research hypothesis coined as the basis for providing a systematic response to the research problem with relevant variables for possible modification of existing theories related to customer service and competitive advantage.

i. There is no significant relationship between quality call network and competitive advantage. 
ii. There is no significant relationship between fast data connection and competitive advantage.

iii. There is no significant relationship between customer correspondence and competitive advantage.

iv. There is no significant relationship between customer support and competitive advantage.

v. There is no significant relationship between warranty and competitive advantage.

\subsection{Concept of Customer Service}

Customer service concerns the priority an organization assigns to servicing customers before, during and after the purchase exchange (Kotler and Armstrong, 2012). In this sense, an organization that values good customer service may spend more money in training employees than the average organization or may proactively interview customers for feedback (Teng, 2019). From a marketing point of view, customer service plays an important role in organizations with the ability to generate income and revenue (Jahanshahi, Gashti et al, 2011; Desfitrina, Zulfadhli et al, 2019). One good customer service experience can change the entire perception a customer holds towards the organization (Agarwal, Kar et al, 2020). Customer service either as tangible or intangible value is design to increase activities related to products or services directly or indirectly to meet customers' expectations towards achieving customers' satisfaction and loyalty (Kursunluoglu, 2011; Minh and Huu, 2016) It also means serving the customer and involves all contact with the customer be it face-to-face, or indirect contact (i.e. dealing with complaint letters) (Juanamasta, Wati et al, 2019). According to Langer, Loidl et al (2017) major customer service challenges in the telecom service industry include quality of call networks, the speed of data, available support for customers, and warranty on telecommunication lines. This sector has mainly been driven by the deregulation of telecom monopolies in many countries within the last decade (Aljawarneh, Sokiyna et al, 2020). The emerging markets force service providers to think in terms of services, quality-of-service (QoS) parameters and service-level agreements (SLA) (Gaillard, Barthel et al, 2014). Therefore, the network and system management platforms have become an indispensable prerequisite for service provisioning in the telecom service industry (Juanamasta, Wati et al, 2019).

\subsection{Quality Call Network}

The quality of call network is paramount a major concern for measuring customer services in the telecom service industry (Kovac and Halas, 2010). According to Jamier (2002), as cited in Alabar, Ode et al (2014) quality call network are one among the series of activities designed to enhance the level of customer satisfaction in the telecom service industry. According to Slalmi, Chaibi et al (2020), the feeling that the customer expectation is met in the telecom industry is usually placed on the quality call network service. On this note, the customer service in respect to the quality of call network relates to the ability to facilitate communication between the service providers and their customers effectively (Minh and Huu, 2016).

\subsection{Fast Data Connection}

Mukherjee and Sharma (2019) expressed that mobile data service is a critical aspect of telecoms as it makes one customer select one telecoms service provider over the other. The internet and mobile telephony have impacted the 20th generation across the globe and segments while new technologies have continued to shape 
and determine the markets (Erickson, 2012). The internet is used for several different activities along with commercial activities (Nazib and Moh, 2021). It is a technology of freedom as mentioned and defined by (Pool, 1973 cited in Mukherjee and Sharma, 2019). Zheng, Shi et al (2020) elucidated that the request for the mobile data connection has become the basic necessity that comes along with smartphones. For instance, Sweet, LeBlanc et al (2020) mentioned and discussed how to be in touch with family, friends and colleagues via smartphones, which has become a critical medium. Mukherjee (2019) explored 3G cellular data service providers in a nascent market in the region of Africa to the south of the Sahara Desert to discover that by improving strategies mobile data service providers could gain trust and loyalty from customers to grow their market reach and expand business volume. Therefore, there exist many factors which have been advanced to the fast growth of usage of data connections among smartphone users in the telecom service industry.

\subsection{Customer Correspondence}

Kotler and Armstrong (2012) expressed that customer service can be described from an angle based on the level of correspondence between an organization and their customers. Also, the customer correspondence helps support the provision of the company's core products such as increasing the quality of the product, solving performance issues of the product, among many other offerings (González-Serrano, Talón-Ballestero et al, 2021). Lewis and Mitchell (2018) opined that customer service correspondence within the service industries have continues to gain importance. Also, consumers in this industry are becoming more aware of the service alternatives and rising standards of service prompted by competitive trends which has solely increased customers' expectations (González-Serrano, Talón-Ballestero et al, 2021). In addition, customers are becoming increasingly critical of the quality of service they experience (Parasuraman, Berry et al, 1993). Expectations are desires or want of consumers on what they feel a service product should offer which are formed based on previous experience with a company and its marketing mix inputs such as physical evidence, process and people (Zeithaml, Parasuraman et al, 2002).

\subsection{Customer Support}

Kotler and Armstrong (2012) expressed that effective customer service is based on in-depth knowledge of consumer behaviour. McLean and Wilson (2016) posited that an average customer wants to be well taken care of. They need someone to understand their needs and help to answer them. According to Borg, Boldt, Rosander et al (2021), customers need someone to hold their hands and walk them through a service process. Customer support starts with the ability to listen to the customer and find out through polite questioning what he/she needs or wants (Chopra, 2014). Donaldson, (2015) mentioned that customer support means providing a quality support product or service that satisfies the needs/wants of a customer and keeps them coming back especially when there are issues. Therefore, customer support is the dedicated team in an organisation that is responsible for providing service assistance to the customers whenever they have issues that are beyond their control.

\subsection{Warranty}

Jack and Murthy (2014) stated that a warranty on organisation service is essential for improving customer satisfaction. Warranty services are essentially fulfilment of the promise an organisation or service provider makes when selling a product, service or contract (Taleizadeh and Sherafati, 2019). Warranty services 
include maintaining, repairing, or replacing a warrantied product or service (Zhang, $\mathrm{He}$ et al, 2020). Sabbagh, Nizam et al (2017) studied the moderation influence of warranty on customer satisfaction's antecedents as empirical evidence from automotive dealerships. It was found that the warranty moderation role is supported wherein the relationship between service quality and customer satisfaction is strengthened by the warranty presence, contrary to the insignificant relationship between product quality and customer satisfaction influenced by the warranty moderator. The empirical results provide evidence that the customer satisfaction value relies on metrics comprising operational measures for service quality and product quality. Warranty service is primarily introduced as a moderator affecting the antecedent relationship in the context of various telecom service providers.

\subsection{Concept of Competitive Advantage}

The term competitive advantage refers to the ability gained through attributes and resources to perform at a higher level than others in the same industry or market (Porter 1980 cited in Wheelen and Hunger, 2012). Hence successfully implemented business strategies and services will lift a firm to superior performance by facilitating the firm with a competitive advantage to outperform current or potential players (Zeithaml, Parasuraman et al, 2002). To gain competitive advantage, many firms adopt various strategies and resources over which it has direct control with the ability to achieve competitive advantage (Afraz, Bhatti et al, 2021). In other words, superior performance outcomes in industry and the production resources reflect competitive advantage (Kryscynski, Coff et al, 2021). According to Dash (2013), competitive advantage refers to a situation whereby organizations products and services are perceived to give better value than that of competitors. Porter (1985) opined that competition is at the centre of the success or failure of organizations, as competition expresses the appropriateness of organizational activities that impact organizational performance such as innovative abilities, culture or structure and strategic implantation. Thus competitive advantage grows as a result of value created by an organization for its customers, this value is superior if it originates from offering lower pricing to that of competitors (Porter, 1985; Kazmi, 2008; Wheelen and Hunger, 2012).

According to Sharp, (1991) citing Porter (1980) in his theory of competitive advantage identified three marketing strategies from the generic strategies which include cost leadership, differentiation and focus. Al-Shibly and Alkhawaldeh (2017) defined the competitive advantage as the ability of the organization to perform its work in a way that is difficult for its competitors to imitate, and the competitive advantage can be achieved by performing functions that create value in the areas of cost reduction compared to competitors or work on their performance in ways that lead to excellence (Zeithaml, Parasuraman et al, 2002). The extent of an organization's competitive advantage is the difference between the perceived value created and the costs to produce the good or service compared to its direct competitors. If the economic value created is greater than that of its competitors, the firm has a competitive advantage; if it is equal to the competitors, the firms are said to have competitive parity; and if it is lower than its rival firms, the firm has a competitive disadvantage (Rothaermel, 2008 as cited in Dash, 2013). Desfitrina, Zulfadhli et al (2019) asserted that an organization is said to have a competitive advantage if the company is seen as superior to its competitors, for example in the quality and price of products produced by, the success of a business can be 
achieved on condition that it has a competitive advantage that continues to be maintained. Competitive advantage can be achieved in various ways, including offering products with minimum prices, or offering products that are unique and more specific than competitors or focus on certain market segments.

\section{Data Analysis}

5.1 Analysis of Demographic Data of Respondents

Table 1

Frequency Distribution of Demographic Data of Respondents

\begin{tabular}{|c|c|c|c|}
\hline \multicolumn{2}{|l|}{ Responses } & Frequency & Percentage (\%) \\
\hline \multirow[t]{3}{*}{ Respondent's Gender } & Female & 180 & 48.6 \\
\hline & Male & 190 & 51.4 \\
\hline & Total & 370 & 100.0 \\
\hline \multirow[t]{6}{*}{ Respondent's age } & $\begin{array}{l}\text { Below } 21 \\
\text { years }\end{array}$ & 0 & 0.0 \\
\hline & $21-30$ years & 110 & 29.7 \\
\hline & $31-40$ years & 190 & 51.4 \\
\hline & $41-50$ years & 54 & 14.6 \\
\hline & $\begin{array}{l}\text { Above } 51 \\
\text { years }\end{array}$ & 16 & 4.3 \\
\hline & Total & 370 & 100.0 \\
\hline \multirow{6}{*}{$\begin{array}{l}\text { Respondents Educational } \\
\text { Qualification }\end{array}$} & WASC/GCE & 13 & 3.5 \\
\hline & $\begin{array}{l}\text { B.Sc. / BA/ } \\
\text { HND }\end{array}$ & 204 & 55.1 \\
\hline & $\begin{array}{l}\text { M.Sc. / } \\
\text { MA/MBA }\end{array}$ & 97 & 26.2 \\
\hline & Ph.D & 0 & 0.0 \\
\hline & Others & 56 & 15.1 \\
\hline & Total & 370 & 100.0 \\
\hline \multirow[t]{4}{*}{ Employment status } & Employed & 141 & 38.1 \\
\hline & Self Employed & 170 & 45.9 \\
\hline & Unemployed & 59 & 16.0 \\
\hline & Total & 370 & 100.0 \\
\hline \multirow[t]{4}{*}{$\begin{array}{l}\text { Respondent's Level of } \\
\text { monthly income }\end{array}$} & $\begin{array}{l}\text { Below } \\
\text { N100,000 }\end{array}$ & 207 & 55.9 \\
\hline & $\begin{array}{l}\text { N100,001- } \\
\text { N500, } 000\end{array}$ & 103 & 27.8 \\
\hline & $\begin{array}{l}\text { Above } \\
\text { N500,001 }\end{array}$ & 60 & 16.2 \\
\hline & Total & 370 & 100.0 \\
\hline \multirow{5}{*}{ 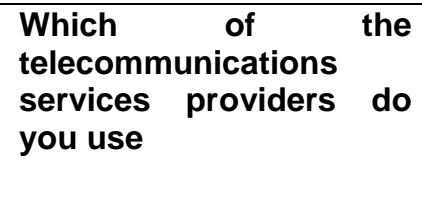 } & Airtel & 97 & 26.2 \\
\hline & Globacom & 53 & 14.3 \\
\hline & MTN & 199 & 53.8 \\
\hline & 9mobile & 21 & 5.7 \\
\hline & Total & 370 & 100.0 \\
\hline
\end{tabular}

Source: Field Survey, 2021 
As shown in the Table 1, 48.6\% of the respondents are of the female gender while $51.4 \%$ of the male gender. It can be inferred from this analysis that most of the respondents are male. Also, $0.0 \%$ of the respondents fall below 21 years, $29.7 \%$ of the respondents fall within $21-30$ years age bracket, $51.4 \%$ within 31 - 40 years, $14.6 \%$ within $41-50$ years, while $4.3 \%$ of the respondents fall within the age bracket of above 51 years. It can be inferred from this analysis that most of the respondents belong to the active workforce, with the age bracket of 31 to 40 years being the modal age. In addition, the table showed that $3.5 \%$ of the respondents are WASC/GCE holders, 55.1\% are BA/B.Sc./HND holders, $26.2 \%$ are M.Sc. / MA/MBA holders, $0.0 \%$ are under $\mathrm{PhD}$ degree holders and $15.1 \%$ of the respondents fall under other categories. This shows that most of the respondents are learned and quite educated within the organization to know the relevance and implication of the study.

The table also showed the respondent's employment status, where $38.1 \%$ of the respondents are employed, $45.9 \%$ of the respondents are self -employed and $16.0 \%$ of the respondents are unemployed. This indicated that the majority of the respondents are self-employed. As regards the level of monthly income, $55.9 \%$ of the respondents earn below $\mathrm{N} 100,000,27.8 \%$ of the respondents earn between $\mathrm{N} 100,001-\mathrm{N} 500,000$ and $16.2 \%$ of the respondents earn above N500,001. This shows that most of the respondents earn below N100,000. While the respondents' telecom services providers reveal that $26.2 \%$ of respondents use Airtel service, $14.3 \%$ of respondents use Globacom service, $53.8 \%$ of respondents use MTN service and $5.7 \%$ of respondents use 9 mobile service This indicated that the majority of the respondents are MTN service subscribers.

\subsection{Hypothesis Testing}

Table 2

Regression Analysis Summary

\begin{tabular}{|l|r|r|r|r|}
\hline Model & $\mathrm{R}$ & R Square & Adjusted R Square & $\begin{array}{c}\text { Std. Error of the } \\
\text { Estimate }\end{array}$ \\
\hline 1 & $.947^{\mathrm{a}}$ & .897 & .850 & .147 \\
\hline
\end{tabular}

Table 3

ANOVA $^{\mathrm{a}}$

\begin{tabular}{|c|c|c|c|c|c|c|}
\hline \multicolumn{2}{|c|}{ Model } & $\begin{array}{l}\text { Sum of } \\
\text { Squares }\end{array}$ & Df & Mean Square & $\mathrm{F}$ & Sig. \\
\hline \multirow[t]{3}{*}{1} & Regression & 1.785 & 1 & \multirow{3}{*}{$\begin{array}{l}1.785 \\
0.608\end{array}$} & \multirow[t]{3}{*}{2.936} & \multirow[t]{3}{*}{$0.01^{b}$} \\
\hline & Residual & 224.338 & 369 & & & \\
\hline & Total & 226.123 & 370 & & & \\
\hline
\end{tabular}

a. Dependent Variable: Competitive Advantage

b. Predictors: (Constant), Customer Services 
Table 4

Coefficients

\begin{tabular}{|c|c|c|c|c|c|}
\hline \multirow[b]{2}{*}{ Model } & \multicolumn{2}{|c|}{$\begin{array}{c}\text { Unstandardized } \\
\text { Coefficients }\end{array}$} & \multirow{2}{*}{\begin{tabular}{|c|}
$\begin{array}{c}\text { standardized } \\
\text { Coefficients }\end{array}$ \\
Beta \\
\end{tabular}} & \multirow[b]{2}{*}{$\mathrm{F}$} & \multirow[b]{2}{*}{ Sig. } \\
\hline & $\mathrm{B}$ & \begin{tabular}{|l} 
Std. Error \\
\end{tabular} & & & \\
\hline $1 \quad$ (Constant) & 2.560 & 0.403 & 0.255 & 14.265 & 0.000 \\
\hline Quality call network & 0.168 & 0.135 & 213 & 1.500 & 0.02 \\
\hline Fast data connection & 0.139 & 0.515 & 237 & 1.569 & 0.01 \\
\hline $\begin{array}{l}\text { Customer } \\
\text { Correspondence }\end{array}$ & 0.103 & 0.458 & 106 & 1.478 & 0.01 \\
\hline Customer support & 0.122 & 0.356 & 240 & 1.360 & 0.01 \\
\hline Warranty & 0.125 & 0.236 & .101 & 1.226 & 0.03 \\
\hline
\end{tabular}

a. Dependent Variable: Competitive advantage

The variables employed in this regression analysis include competitive advantage as a dependent variable and customer service as an independent variable in testing the hypotheses. The $\mathrm{R}$ square was $89.7 \%$ from the overall model summary.

This is further expressed as $=Y^{n}=a+b 1 X 1+b 2 X 2+b 3 X 3+b 4 X 4+b 5 X 5$, where $Y^{r}$ is the dependent variable, $\mathrm{a}$ is the intercept, $\mathrm{XI}, \mathrm{X} 2, \mathrm{X} 3, \mathrm{X} 4, \mathrm{X} 5$ are the components of the independent variable and b1, b2, b3, b4, b5 are the coefficient of the independent variables.

$$
\begin{aligned}
& \mathrm{Y}=\mathrm{CA}=\text { Dependent variable }=\text { Competitive advantage } \\
& \mathrm{a}=\text { intercept } \\
& \mathrm{X} 1=\mathrm{Q} C=\text { Quality Call Network } \\
& \mathrm{X} 2=\mathrm{FD}=\text { Fast Data Connection } \\
& \mathrm{X} 3=\mathrm{CC}=\text { Customer Correspondence } \\
& \mathrm{X} 4=\mathrm{CS}=\text { Customer Support } \\
& \mathrm{X} 5=\mathrm{W}=\text { Warranty } \\
& \mathrm{b} 1=\text { Coefficient for quality call network } \\
& \mathrm{b} 2=\text { Coefficient for Fast Data Connection } \\
& \mathrm{b} 3=\text { Coefficient for Customer Correspondence } \\
& \text { b4 = Coefficient for Customer Support } \\
& \text { b5 = Coefficient for Warranty }
\end{aligned}
$$
therefore:

Thus based on regression analysis, the regression model for this study is,

$\mathrm{CA}=a+\beta 1 \mathrm{QC}+\beta 2 \mathrm{FD}+\beta 3 \mathrm{CC}+\beta 4 \mathrm{CS}+\beta 5 \mathrm{~W}$

$C A=0.255+0.213 Q C+0.237 F D+0.106 C C+0.240 C S+0.101 W$

R square $=0.897$

The above analysis shows how the independent variable (customer service in form of quality call network, fast data connection, customer correspondence, customer support, warranty) affects the dependent variable (competitive advantage).

$\mathrm{H}_{01}$ : There is no significant relationship between quality call network and competitive advantage.

The $\mathrm{R}$ square value of .829 indicated that about $82.9 \%$ of the total systematic variations in what is competitive advantage were due to the variations in quality call 
network. This means that only $17.1 \%$ of the total systematic variations that incorporate competitive advantage are left unexplained hence captured by the stochastic error term in the estimated model.

Thus, as a result of the test of hypothesis, the null hypothesis one should be rejected and alternative hypothesis one should be accepted stated as there is a significant relationship between quality call network and competitive advantage.

$\mathrm{H}_{02}$ : There is no significant relationship between fast data connection and competitive advantage.

The R square value of .912 indicated that about $91.2 \%$ of the total systematic variations in competitive advantage were due to the variations to the fast data connection. This means that only $8.8 \%$ of the total systematic variations in competitive advantage are left unexplained hence captured by the stochastic error term in the estimated model. Thus, as a result the test of hypothesis null hypothesis two, should be rejected and the alternative hypothesis two should be accepted stated as there is a significant relationship between fast data connection and competitive advantage.

$\mathrm{H}_{03}$ : There is no significant relationship between customer correspondence and competitive advantage.

The $R$ square value of .658 indicated that about $65.8 \%$ of the total systematic variations in what is a competitive advantage were due to the variations in a customer correspondence. This means that only $34.2 \%$ of the total systematic variations in competitive advantage are left unexplained hence captured by the stochastic error term in the estimated model. Thus, as a result of the test of hypothesis, the null hypothesis three should be rejected and alternative hypothesis three should be accepted stated as there is a significant relationship between customer correspondence and competitive advantage.

$\mathrm{H}_{04}$ : There is no significant relationship between customer support and competitive advantage.

The R square value of .968 indicated that about $96.8 \%$ of the total systematic variations in competitive advantage were due to the variations to customer support. This means that only $3.2 \%$ of the total systematic variations in competitive advantage are left unexplained hence captured by the stochastic error term in the estimated model. Thus, as a result, the test of hypothesis null hypothesis four should be rejected and the alternative hypothesis four should be accepted stated as there is a significant relationship between customer support and competitive advantage.

$\mathrm{H}_{05}$ : There is no significant relationship between warranty and competitive advantage.

The $R$ square value of .521 indicated that about $51.2 \%$ of the total systematic variations in what is competitive advantage were due to the variations in warranty. This means that only $47.8 \%$ of the total systematic variations in competitive advantage are left unexplained hence captured by the stochastic error term in the estimated model. Thus, as a result of the test of hypothesis, the null hypothesis five should be rejected and alternative hypothesis five should be accepted stated as there is a significant relationship between warranty and competitive advantage. 


\section{Discussion of Findings}

The findings indicated there is a significant relationship between quality call network and competitive advantage. The majority of the respondents stated that quality call networks make allows customers to patronize the telecommunications service provider over competitors. Also, the respondents strongly agreed that quality call networks are a key aspect of customer service for telecommunications service providers. The findings were in line with the previous works of Alabar, Ode et al (2014) regarding key areas of competitive advantage in Nigerian mobile telephone markets based on emphasis that quality of calls was used to measure customer service quality. Furthermore, the study findings aligned with Ashfaq (2019) giving empirical evidence regarding the significant relationship between quality of call network and competitive edge in the telecom sector in Afghanistan.

The findings from this study further indicated the significant relationship between fast data connection and competitive advantage. The majority of the respondents identified fast data connection as the reason for choosing one telecommunication service provider over competitors. The findings were in agreement with previous studies of Dash (2013) regarding the competitive advantage and its impact on the design of strategy, Donaldson (2015) and Desfitrina, Zulfadhli et al (2019) based on the ideology that customer service is a competitive strategy through key services such as fast data connection in the telecommunication industry. The argument established from the findings of the study shows that fast data connection is an element of customer service which gives a corporate competitive advantage to telecommunications service providers in Nigeria. In addition, the study findings indicated that there is a significant relationship between customer correspondence and competitive advantage. The majority of the respondents established that the way their telecommunications service provider corresponds and communicates with customers allows for increase patronage and competitive advantage. The findings were further in line with previous studies of Oghojafor, Ladipo et al (2014), Langer, Loidl et al (2017), and Desfitrina Zulfadhli et al (2019) based on the fact that customer correspondence and feedback are critical for customers in choosing an organization over the other.

The study findings also indicated that there is a significant relationship between customer support and competitive advantage. The respondents showed that the extent to which a telecommunications service provider can handle issues and support customers when they have challenges with products and services is a critical competitive edge factor. The findings agreed with the previous studies of Ogunnaike, Salau et al (2016) and Ladipo, Agada et al (2020) based on the evaluation of customer service and customer retention from a comparative analysis of telecommunication service providers. Finally, the study findings showed that there is a significant relationship between warranty and competitive advantage. The assurance of excellent services provider by telecommunications firms gives them a competitive advantage. The findings agreed with Obasan and Soyebo (2012), and Desfitrina Zulfadhli et al (2019) based on the competitive edge attained from warranties used in services. 


\section{Conclusions, Recommendations and Suggestions for Future Studies}

This study investigated the effect of customer service on corporate competitive advantage based on the perspective of selected firms in telecommunications companies in Lagos state. As a result of the data analysis and test of hypotheses, several findings were arrived at. In line with the research objectives and questions, five hypotheses were tested and all null hypotheses were rejected with a p-value lower than significant level 0.05 . Based on the findings of the study, it can be concluded that customer service and its components (quality call network, fast data connection, customer correspondence, customer support and warranty) have a significant effect on corporate competitive advantage based on the perspective of selected firms in telecommunications companies in Lagos state. The conclusion of this study based on the research objectives and questions show that customer support has the most significant effect on competitive advantage in telecommunications services in Nigeria, followed by a fast data connection, then quality call network, customer correspondence and warranty. The study concludes that regarding telecommunications services in Nigeria customer service is a critical element in building corporate competitive advantage.

The independent variables as examined in this study implies that they are very crucial in achieving a competitive advantage in the telecommunications industry. Therefore customer services in terms of quality call network, fast data connection, customer correspondence, customer support and warranty, should all be improved upon if telecommunications service providers are to attain sustainable competitive advantage and attain sustainable growth. This study centred on investigating the effect of customer service on corporate competitive advantage based on the perspective of selected firms in telecommunications companies in Lagos state. As such future studies can be done in other key areas of marketing management that affect corporate competitiveness such as product quality, pricing strategy, promotional strategy and distribution strategy. Also, the study was based on only a quantitative research approach hence further studies can be done through a qualitative research approach or mixed research approach. Finally, the study focused on the Nigerian Telecommunications service industry hence further studies can consider other organizations or industries like Fast Moving Consumer Goods, Banking and Manufacturing.

\section{REFERENCES}

Adeleke, R. (2020), Digital divide in Nigeria: The role of regional differentials. African Journal of Science, Technology, Innovation and Development, 1-14.

Afraz, M. F., Bhatti, S. H., Ferraris, A., and Couturier, J. (2021), The impact of supply chain innovation on competitive advantage in the construction industry: Evidence from a moderated multi-mediation model. Technological Forecasting and Social Change, 162, 120370.

Agarwal, A., Kar, A. K., and llavarasan, P. V. (2020), Factors affecting customer service Engagement-Six cases assessing strengths and weaknesses for 
telecom and payment service providers. In Proceedings of ICETIT 2019 (pp. 775-784). Springer, Cham.

Akingbade, W. A. (2021), Strategic Options for Improved Organizational Performance in the Nigerian Telecommunication Industry: Miles and Snow Approach. Acta Universitatis Danubius. CEconomica, 17(2), 87-96.

Alabar, T. T. Ode E. andGbande, I. R. (2014), Service quality and customer satisfaction in Nigerian mobile Telephony. British Journal of Marketing Studies. 5(1).37-49.

Aljawarneh, N. M., Sokiyna, M., Obeidat, A. M., Alomari, K. A. K., Alradaideh, A. T., and Alomari, Z. S. (2020), The Role of CRM fog computing on innovation and customer service quality: An empirical study.

Al-Shibly, M. S., and Alkhawaldeh, K. H. (2017), The Impact of Marketing by Relationships to Achieve Competitive Advantage A Case Study" Cellular Telecommunication Companies in Jordan. Journal of marketing management, 5(2), 31-43.

Ashfaq, M. (2019), After sales service, customer satisfaction and loyalty in telecom sector. Journal of Applied Structural Equation Modeling, 3(1),31-42.

Borg, A., Boldt, M., Rosander, O., and Ahlstrand, J. (2021), E-mail classification with machine learning and word embeddings for improved customer support. Neural Computing and Applications, 33(6), 1881-1902.

Chopra, K. (2014), Empirical study on role of customer service in delivering satisfaction at branded retail outlets in Pune. Science Direct Procedia Economics and Finance, 11(1), 239 - 246.

Dash, A. K. (2013), Competitive advantage: its importance and impact on design of strategy. International Journal of Application or Innovation in Engineering and Management (IJAIEM).2(12),7-11

David Mc A, B. (2013), Service quality and customer satisfaction in the airline industry: A comparison between legacy airlines and low-cost airlines. American Journal of Tourism Research, 2(1), 67-77.

Desfitrina, M. M., Zulfadhli, O. and Widarti, S.S (2019), Good Service Strategies Affect Competitive Advantage. International Review of Management and Marketing, 9(6), 135-144.

Donaldson, B. (2015), Customer service as a competitive strategy, Journal of Strategic Marketing, 3:2, 113-126.

Erickson, F. (2012), Qualitative research methods for science education. In Second international handbook of science education (pp. 1451-1469). Springer, Dordrecht.

Gaillard, G., Barthel, D., Theoleyre, F., and Valois, F. (2014), Service Level Agreements for Wireless Sensor Networks: A WSN operator's point of view. In 2014 IEEE Network Operations and Management Symposium (NOMS) (pp. 1-8). IEEE.

González-Serrano, L., Talón-Ballestero, P., Muñoz-Romero, S., Soguero-Ruiz, C., and Rojo-Álvarez, J. L. (2021), A Big Data Approach to Customer 
Relationship Management Strategy in Hospitality Using Multiple Correspondence Domain Description. Applied Sciences, 11(1), 256.

Hallencreutz, J., and Parmler, J. (2019), Important drivers for customer satisfactionfrom product focus to image and service quality. Total quality management and business excellence, 1-10.

Hayes, A. F., and Coutts, J. J. (2020), Use omega rather than Cronbach's alpha for estimating reliability. But.... Communication Methods and Measures, 14(1), 1-24.

Hodgson, G. M. (1993), Theories of economic evolution: a preliminary taxonomy. The Manchester School, 61(2), 125-143.

Hunt, S. D., and Arnett, D. B. (2004), Market segmentation strategy, competitive advantage, and public policy: Grounding segmentation strategy in resource-advantage theory. Australasian Marketing Journal (AMJ), 12(1), 7-25.

Ishola, O. A., and Olusoji, M. O. (2020), Service Sector Performance, Industry and Growth in Nigeria. International Journal of Service Science, Management, Engineering, and Technology (IJSSMET), 11(1), 31-45.

Jack, N. and Murthy, D. N. P. (2014), Warranty servicing strategies to improve customer satisfaction. IMA Journal of Management Mathematics 15(2)

Jahanshahi, A. A. Gashti, M. A. H. Mirdamadi, S. A., Nawaser, K. andKhaksar, S. M. S. (2011), Study the effects of customer service and product quality on customer satisfaction and loyalty. International Journal of Humanities and Social Science.1 (7), 253

Juanamasta, I. G., Wati, N. M. N., Hendrawati, E., Wahyuni, W., Pramudianti, M., Wisnujati, N. S., and Umanailo, M. C. B. (2019), The role of customer service through customer relationship management $(\mathrm{Crm})$ to increase customer loyalty and good image. International Journal of Scientific and Technology Research, 8(10), 2004-2007.

Kazmi, A. (2008), Strategic management and business policy (3rd edn). New Delhi: McGraw-Hill.

Kotler, P. and Armstrong, G. (2012), Principles of marketing, (12th ed.), Upper Saddle River: Pearson Education Inc.

Kovac, A., and Halas, M. (2010), Analysis of influence of network performance parameters on VolP call quality. Knowledge in Telecommunication Technologies and Optics, 26-30.

Kryscynski, D., Coff, R., and Campbell, B. (2021), Charting a path between firmspecific incentives and human capital-based competitive advantage. Strategic Management Journal, 42(2), 386-412.

Kursunluoglu, E. (2011), Customer service effects on customer satisfaction and customer loyalty: A field research in shopping centers in Izmir City - Turkey. International Journal of Business and Social Science, 2(17),52-60.

Ladipo, P. K. A., Agada, S. A. and Ighomereho, O. S. (2020), Moderating factors and customer loyalty of selected hotels in Lagos state, Nigeria. Journal of Asian Business Strategy. 10(1), 1-12. 
Langer, M., Loidl, S. andNerb, M. (2017), Customer service management: a more transparent view to your subscribed services. Leibniz Supercomputing Center, 1-12.

Lewis, B. R. and Mitchell, V. W. (2018), Defining and measuring the quality of customer service. Marketing Intelligence and Planning, 8(6), 11 - 17.

Lim, K. B., Yeo, S. F., Goh, M. L. andKoh, W. M. (2018), A study on consumer switching behaviour in Telecommunication industry. Journal of Fundamental and Applied Sciences.10 (6).1143-1153.

Matthew, U. O., Kazaure, J. S., John, O., and Haruna, K. (2021), Telecommunication Business Information System and Investment Ecosystem in a Growing Economy: A Review of Telecom Investment in Nigeria. International Journal of Information Communication Technologies and Human Development (IJICTHD), 13(2), 1-20.

McLean, G., and Wilson, A. (2016), Evolving the online customer experience... is there a role for online customer support? Computers in Human Behavior, $60,602-610$.

Minh, N. V. and Huu, N. H. (2016), The relationship between service quality, customer satisfaction and customer loyalty: An Investigation in Vietnamese Retail Banking Sector. Journal of Competitiveness. 8(2), 103 - 116.

Mukherjee, N. (2019), Effect of Mobile Data Service on Customer Retention, Loyalty and Satisfaction in Indian Market (Doctoral dissertation, Chitkara University Punjab).

Mukherjee, N. K. and Sharma, S. (2019), Effect of Mobile Data Service on Customer Loyalty, Retention and Satisfaction in Indian Industry. Journal of Advanced Research in Dynamical and Control Systems 11(10-SPECIAL ISSUE):12601271

National Bureau of statistics (NBS), Nigerian Telecommunications sector report (2016), Retrieved on $21^{\text {st }}$ of January 2021 from https//: National Bureau of Statistics Telecommunications\%20Report\%202016\%20Q2\%20(1).pdf

Nazib, R. A., and Moh, S. (2021), Energy-Efficient and Fast Data Collection in UAVAided Wireless Sensor Networks for Hilly Terrains. IEEE Access, 9, 2316823190.

Nunnally, J. C. (1975), Psychometric theory-25 years ago and now. Educational Researcher, 4(10), 7-21.

Obasan, K. A. and Soyebo Y. A. (2012), Assessing the effectiveness of promotion as marketing tool in Nigerian telecommunication industry. Journal of Emerging Trends in Economics and Management sciences.3 (1).1-6.

Oghojafor, B. E. A. Ladipo, K.A. P., Ighomereho, O. S. andOdunewu, A. V. (2014), Determinants of customer satisfaction and loyalty in the Nigerian telecommunications industry. British Journal of Marketing Studies.2 (5).6783. 
Ogunnaike, O. O., Salau, O., Sholarin, A. andTaiye T. B. (2016), Evaluation of customer service and retention; a comparative analysis of telecommunication service providers. European Journal of Business and Social Sciences.3 (8)273-288.

Oyedijo, A. (2012), Strategic agility and competitive performance in the Nigerian telecommunication industry: an empirical investigation. American International Journal of Contemporary Research, 2(3), 227-237.

Pallant, J. F., and Lae, L. (2002), Sense of coherence, well-being, coping and personality factors: further evaluation of the sense of coherence scale. Personality and individual differences, 33(1), 39-48.

Parasuraman, A., Berry, L. L., and Zeithaml, V. A. (1993), More on improving service quality measurement. Journal of retailing, 69(1), 140-147.

Peterson, R. A. (1994), A meta-analysis of Cronbach's coefficient alpha. Journal of consumer research, 21(2), 381-391.

Porter, M. E. (1980), Industry structure and competitive strategy: Keys to profitability. Financial analysts journal, 36(4), 30-41.

Porter, M.E. (1985), Competitive Advantage: Creating and sustaining superior performance. The Free Press, New York.

Sabbagh, O., Nizam A. M. Rahman, M. N., Ismail, W. R., Hirwani, W. M. andHussain, W. (2017), The moderation influence of warranty on customer satisfaction's antecedents: an empirical evidence from automotive dealerships. Service Industries Journal, 37(5-6):381-407

Slalmi, A., Chaibi, H., Saadane, R., Chehri, A., and Jeon, G. (2020), 5G NB-loT: Efficient network call admission control in cellular networks. Concurrency and Computation: Practice and Experience, e6047.

Steven, A. B., Yazdi, A. A., and Dresner, M. (2016), Mergers and service quality in the airline industry: A silver lining for air travelers? Transportation Research Part E: Logistics and Transportation Review, 89, 1-13.

Sweet, K. S., LeBlanc, J. K., Stough, L. M., and Sweany, N. W. (2020), Community building and knowledge sharing by individuals with disabilities using social media. Journal of computer assisted learning, 36(1), 1-11.

Taleizadeh, A. A., and Sherafati, M. (2019), A three-level supply chain with warranty services, pricing and marketing decisions. Journal of Modelling in Management.

Teng, H. Y. (2019), Job crafting and customer service behaviors in the hospitality industry: Mediating effect of job passion. International Journal of Hospitality Management, 81, 34-42.

Wheelen, T. L. and Hunger, J. D. (2012), Strategic management and business policy. 10th ed. United States of America: Pearson Prentice Hall.

Xiao, L., and Kumar, V. (2021), Robotics for customer service: a useful complement or an ultimate substitute? Journal of Service Research, 24(1), 9-29.

Zeithaml, V. A., Parasuraman, A., and Malhotra, A. (2002), Service quality delivery through web sites: a critical review of extant knowledge. Journal of the academy of marketing science, 30(4), 362-375. 
Zhang, Y., He, Z., He, S., Cai, K., and Wang, D. (2020), Manufacturer warranty service outsourcing strategies in a dual-channel supply chain. International Transactions in Operational Research, 27(6), 2899-2926.

Zheng, X., Shi, X., and Yang, F. (2020), Media system dependency and user attachment in social QandA communities: do active users and lurkers differ? Information Technology and People, 3(5), 112-131. 